\title{
Peri-urban conservation in the Mondah forest of Libreville, Gabon: Red List assessments of endemic plant species, and avoiding protected area downsizing
}

\author{
G. Walters, E. Ngagnia Nijabounda, D. Inabanga, J. P. Biteau, O. Hymas \\ L. J. T. White, A. - M. Ndong Obiang, P. Ndong Ondo, K. J. Jeffiery \\ O. LACHENAUD and T. STÉVART
}

\begin{abstract}
Urban development is an increasing threat to the integrity of formerly remote protected areas, in some cases resulting in their downgrading, downsizing or degazetting. One-quarter of previously remote protected areas are now within $17 \mathrm{~km}$ of a city and thus face the threat of urbanization. Here we describe a case of avoided downgrading, downsizing and degazetting of a protected area in the Mondah forest of Gabon, north of Libreville. Since its creation in 1934 the Forêt Classée de la Mondah has been downsized regularly, losing $40 \%$ of its area over 80 years. During this time the forest surrounding the Forêt Classée was subject to usage for urban and peri-urban needs, including agriculture, sand extraction, collection of medicinal plants, ceremonies, and housing construction. In 2010 the area was threatened with further downsizing. The presence of narrowly endemic plant species in the area was suspected, and mapping and evaluation of these species was proposed in an effort to maintain the protected area boundaries.
\end{abstract}

G. WALters ${ }^{*} \dagger$ (Corresponding author) and T. StÉVART $¥ \bigotimes$ Institut de Pharmacopée et de Médecine Traditionnelle, Herbier National du Gabon, B.P. 1135 Libreville, Gabon. E-mail g.walters@ucl.ac.uk

E. Ngagnia Ndjabounda and D. Ikabanga Département de Biologie, Université des Sciences et Techniques de Masuku, Franceville, Gabon

J. P. BITEAU Jardi-Gab, Libreville, Gabon

O. Hymas Department of Anthropology, University College London, Gower Street, London, UK, and Institute of Zoology, Zoological Society of London, UK

L. J. T. White ${ }^{* *}$, A.-M. Ndong Obiang, P. Ndong Ondo and K. J. JefFery ${ }^{* *}$ Agence Nationale des Parcs Nationaux, Libreville, Gabon

O. Lachenaud National Botanic Garden of Belgium, Meise, Belgium, and Service d'Evolution, Biologie et Ecologie, Université Libre de Bruxelles, Brussels Belgium

${ }^{\star}$ Current address: Global Forest and Climate Change Programme, IUCN, 28 rue Mauverney, 1156 Gland, Switzerland

$\dagger$ Also at: Department of Anthropology, University College London, Gower Street, London, UK

\$Also at: Central African Red List Authority, Species Survival Commission, IUCN

\$Also at: Africa and Madagascar Department, Missouri Botanical Garden St. Louis, USA, Herbarium et Bibliothèque de Botanique Africaine, Faculté des Sciences, Université Libre de Bruxelles, Brussels, Belgium, and National Botanic Garden of Belgium, Meise, Belgium

Also at: School of Natural Sciences, University of Stirling, Stirling, UK

**Institut de Recherche en Ecologie Tropicale, Libreville, Gabon

Received 10 January 2015. Revision requested 19 January 2015.

Accepted 28 January 2015. First published online 14 August 2015.
Botanical field work, including ex situ conservation measures and participant observation in nearby forest communities, was conducted; 24 endemic species, all threatened by urbanization, were evaluated using the criteria for the IUCN Red List of Threatened Species. The borders of the protected area were maintained because of its role in maintaining irreplaceable habitat for threatened species. The area was renamed Raponda Walker Arboretum in 2012.

Keywords Degazettement, downsizing, endemic species, Gabon, IUCN Red List of Threatened Species, protected area, urbanization

\section{Introduction}

D rotected areas are considered to be the most effective strategy for protecting biodiversity (Chape et al., 2008), yet in many places urban development is an increasing threat to many formerly remote protected areas (Margules \& Pressey, 2000), and conservation planning must now take into account trends in human settlement (Theobald et al., 2000). Urban space may compete simultaneously with biodiversity, forest cover, protected areas, agricultural space and food security (Ahrends et al., 2010; DeFries et al., 2010; Smith et al., 2010; Gordon et al., 2012), with $54 \%$ of the human population now living in urban areas (United Nations, 2014), and this may have a negative impact on protected areas.

Downgrading, downsizing and degazetting of protected areas is an increasing concern (downgrading is an increase in use of an existing protected area, downsizing a reduction in territory, and degazetting the complete elimination of the area's protected status; Mascia \& Pailler, 2011). Five hundred such cases have been recorded in 57 countries, with the main causes being attributed to industrial-scale resource extraction and development (Mascia et al., 2014), often linked inextricably to the presence or development of urban areas. One-quarter of protected areas are within $17 \mathrm{~km}$ of a city, and this distance is decreasing. An estimated $8 \%$ of species categorized as threatened on the IUCN Red List are threatened by urbanization (McDonald et al., 2008), which is 


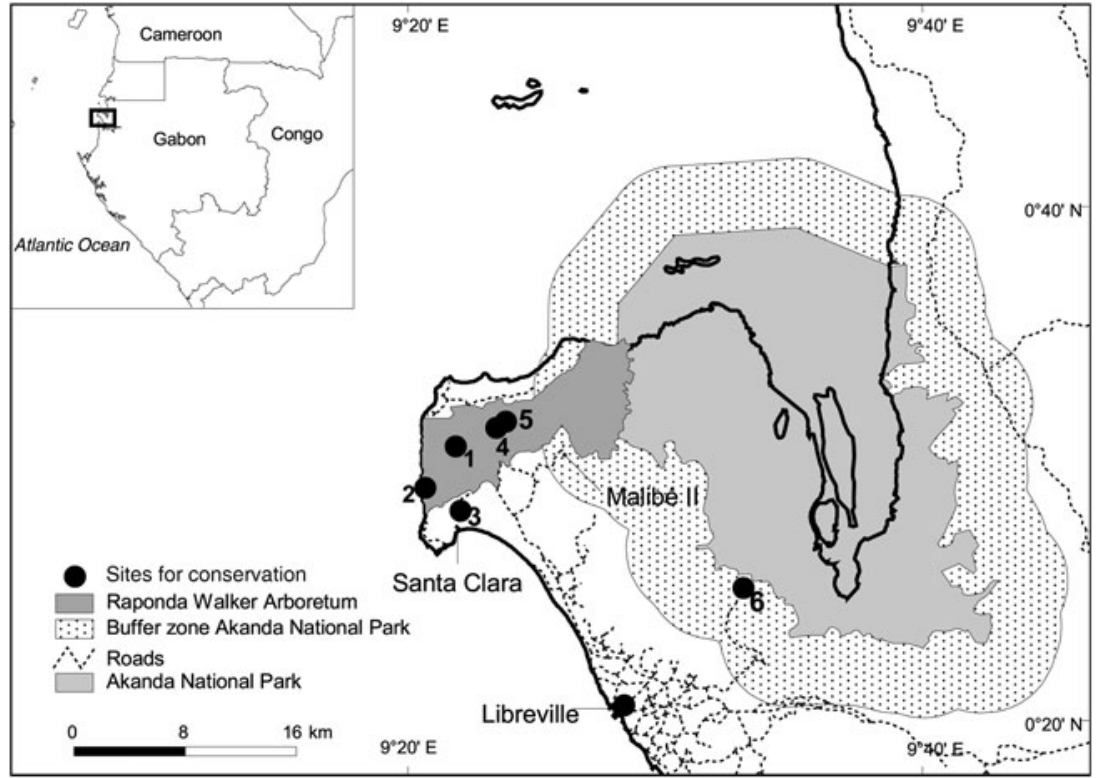

FIg. 1 The Raponda Walker Aboretum on the Libreville peninsula, Gabon. Numbers denote important sites for conservation (Table 2) likely to have a greater negative effect on native species (Aronson et al., 2014), and range-restricted species are more vulnerable when urban areas comprise part of their range (McDonald et al., 2008). Furthermore, urban areas are growing faster in biodiverse coastal zones and hotspots (Elmqvist et al., 2013). Maintaining effective protection, especially for threatened species, is best done through protected areas (Joppa \& Pfaff, 2009), the main role of which is to separate biological resources from their threats (Margules \& Pressey, 2000). Few studies have focused on the impacts of urbanization on protected areas in Africa, Asia and Latin America (Magle et al., 2012), or on the permanence of protected areas under increasing pressure from urbanization.

In Gabon $11 \%$ of land is protected by a network of National Parks (République Gabonaise, 2007), and in 2014 there was a governmental commitment to protect marine areas. With a low human population density $(5.8$ people per $\mathrm{km}^{2}$ ), urbanization presents a low level of threat to the overall protected area network. It is a growing concern in areas of urban development, however, such as the capital city, Libreville, where peri-urban expansion is encroaching upon two nearby National Parks and a Forest Reserve. Here, a rare case of protected area downgrading, downsizing and degazetting has been observed (sensu Mascia et al., 2014): a Forest Reserve was downsized gradually over a period of 80 years, and by 2010 its future was under threat. Several strictly endemic plant species were thought to be present in the area but there was a lack of information about their conservation status and distribution. Here we describe how the assessment of endemic species was used to improve the delimitation of a protected area and prevent further downgrading, downsizing and degazetting, using the following steps: refinement of the endemic species list; assessment of threats to habitat; evaluation of the species, using the criteria for the IUCN Red List of Threatened Species; identification of key conservation sites; delimitation of a new protected area using these datasets; and application of ex situ conservation techniques.

\section{Study area and conservation context}

Coastal Gabon is part of the Guineo-Congolian centre of endemism for plants (White, 1983). The rate of plant endemism in Gabon is $11-13 \%$ (Sosef et al., 2006), higher than in neighbouring countries (Lachenaud, 2009; Onana, 2010). Floristic richness has been underestimated for coastal areas (Dauby et al., 2008; Harris et al., 2012), where the flora is distinct from that of the adjacent mountainous areas (Dauby et al., 2014).

Urban coastal areas are subject to intense migration, with Gabon's rate of urbanization at $87 \%$, the highest in Africa (United Nations, 2014). In Central Africa rural residents migrate to peri-urban and urban areas to find employment, while also maintaining subsistence activities (Trefon, 2003; East et al., 2005; Omasombo, 2005; Socpa, 2010).

The Mondah forest is on the Libreville peninsula, c. 21 $\mathrm{km}$ north of the centre of Libreville (Fig. 1). The Mondah area receives $3,000-3,500 \mathrm{~mm}$ of rainfall per year, with a mean temperature of $25^{\circ} \mathrm{C}$ and a dry season during JuneSeptember (Vande Weghe, 2005). The area is characterized by valleys and rivers, often creating hyper humid climates and diverse vegetation types. This ecosystem extends between the Libreville peninsula and across the Corisco Bay into Equatorial Guinea's Rio Muni. The Mondah forest has been inhabited at least since 3400 BP (Clist, 2005) and commercially exploited for forest resources (dyewoods and salt) at least since the 140os (Patterson, 1975); timber 
exploitation began in the late 180os (Quilliard, 1920; Meye, 1969). In the 1960s six ethnic groups resided there (Deschamps, 1962) but as a result of recent immigration the forest now supports 24 ethnic groups (Ikabanga, 2011). People use this peri-urban forest for subsistence farming, charcoal production, artisanal logging, sand extraction (Trefon, 2003) and traditional medicine (Delhotal, 2009; Koumba-Madingou, 2009), with a noticeable difference in the resource usage of rural and urban people. The Forêt Classée de la Mondah was created in 1934 by the colonial French administration as a timber production forest and research area (including for establishing plantations of Aucoumea klaineana, a subendemic timber species), and from 1951 was managed by the National Forestry School. The management objectives for the forest were based on production of A. klaineana, and research into the species. Later, the forest was used by the National Forestry School for educational purposes. Only in the 1990s was the role of the area in protecting biodiversity highlighted (Wilks, 1990). Until the start of this study the forest had been under the jurisdiction of the National Forestry School but in 2010 there was a proposed change in administration, giving management responsibility to Gabon's National Parks Agency, and downsizing of the protected area was proposed.

Originally the protected area comprised 12,400 ha (Ministère des Eaux et Forêts, 1997) but a series of legislative changes during 1951-2004 successively reduced it to $<5$,000 ha by 2004 (Figs $2 \& 3$ ). There were various reasons for the downsizing, including the according of private inholdings and construction of public utilities; however, the 2004 downsizing, which four of the authors observed, was predominantly to convert land for housing in the southern portion (where 2,00o ha were lost; Table 1). Degradation of the forest has been noted since 1970, when it was attributed to sand extraction, agricultural activities and the creation of villages near forestry camps (Ministère des Eaux et Forêts, 1997). Although in the past the Forêt Classée de la Mondah had been subject to disturbance through resource extraction and plantation establishment, some forest recovery seemed likely. However, during $1960-200055 \%$ of the forest was transformed into secondary forest (Nziengui et al., 2008), making the Mondah likely to be an Endangered ecosystem according to IUCN criteria for the Red List of Ecosystems (Keith et al., 2013). Although the rate of deforestation in Gabon is low overall $\left(<_{1} \%\right.$ per year; COMIFAC, 2010), mapping shows the highest level of deforestation occurs in the Mondah area (Hansen et al., 2013).

By 2010 the situation was critical. Not only had most of the previously downsized forest been cleared for peri-urban land use, but increasing human activity was encroaching upon the remaining protected area, and management capacity was inadequate. The city had expanded such that its outer edge was within $5 \mathrm{~km}$ of the forest, and the forest was becoming increasingly degraded. At this time the National Parks Agency put forward a proposal to take over management of the forest under newly defined limits. A draft decree proposed the creation of a National Park comprising a terrestrial zone (henceforth the Centre; 1,318 ha) and marine zones (1,610 ha) surrounded by a buffer zone $(5,715 \mathrm{ha})$. The proposed limits were based on earlier plans to target protection efforts on a core area of intact forest, allowing controlled development in the degraded surrounding areas, under buffer zone management policies (Wilks, 1990). However, it was not clear how the buffer zone would be managed or if there were endemic plant species in the forest outside the Centre. The National Parks Agency was willing to extend the boundaries of the proposed protected area if evidence of threatened or endemic species was provided.

Although originally the Mondah forest was considered to be of local interest only (Doumenge et al., 2003), it was suspected to contain c. 50 restricted-range plant species endemic to the Libreville Peninsula, some of them extending to the adjacent Corsico Bay area in Equatorial Guinea, and some of which were in the process of being described (Kenfack, 2011; Breteler, 2012; Lachenaud et al., 2013b). Only two species had been evaluated using the IUCN Red List criteria (IUCN, 2013) and thus the conservation status of most of the species was unknown. To inform the process of boundary delimitation for the new protected area, evidence of subpopulations of restricted-range species needed to be provided to the National Parks Agency, along with an assessment of their irreplaceability (i.e. whether the habitat is conserved elsewhere) and vulnerability (i.e. the risk of the area being transformed to other land uses; Margules \& Pressey, 2000).

Given the risk of extinction of endemic species, ex situ conservation was considered as a solution in the event of downsizing, if endemic species were found outside the reduced protected area. Ex situ conservation techniques, or cultivation of species outside their native habitats, can help to ensure that threatened species are maintained (Müller \& Eriksson, 2013), particularly when the habitats are so threatened that the species are at risk of extinction.

\section{Methods}

Refinement of the list of endemic plant species A list of endemic plant species in the Libreville area was compiled through searches of herbarium records, botanical literature (e.g. Sosef et al., 2006) and the database of Naturalis Biodiversity Center in the Netherlands. For each species, information on family, habitat, collection dates and localities, distinctive identification criteria, and phenology was compiled from botanical journals and type specimens. Many specimens had imprecise records of localities, making relocation difficult. 


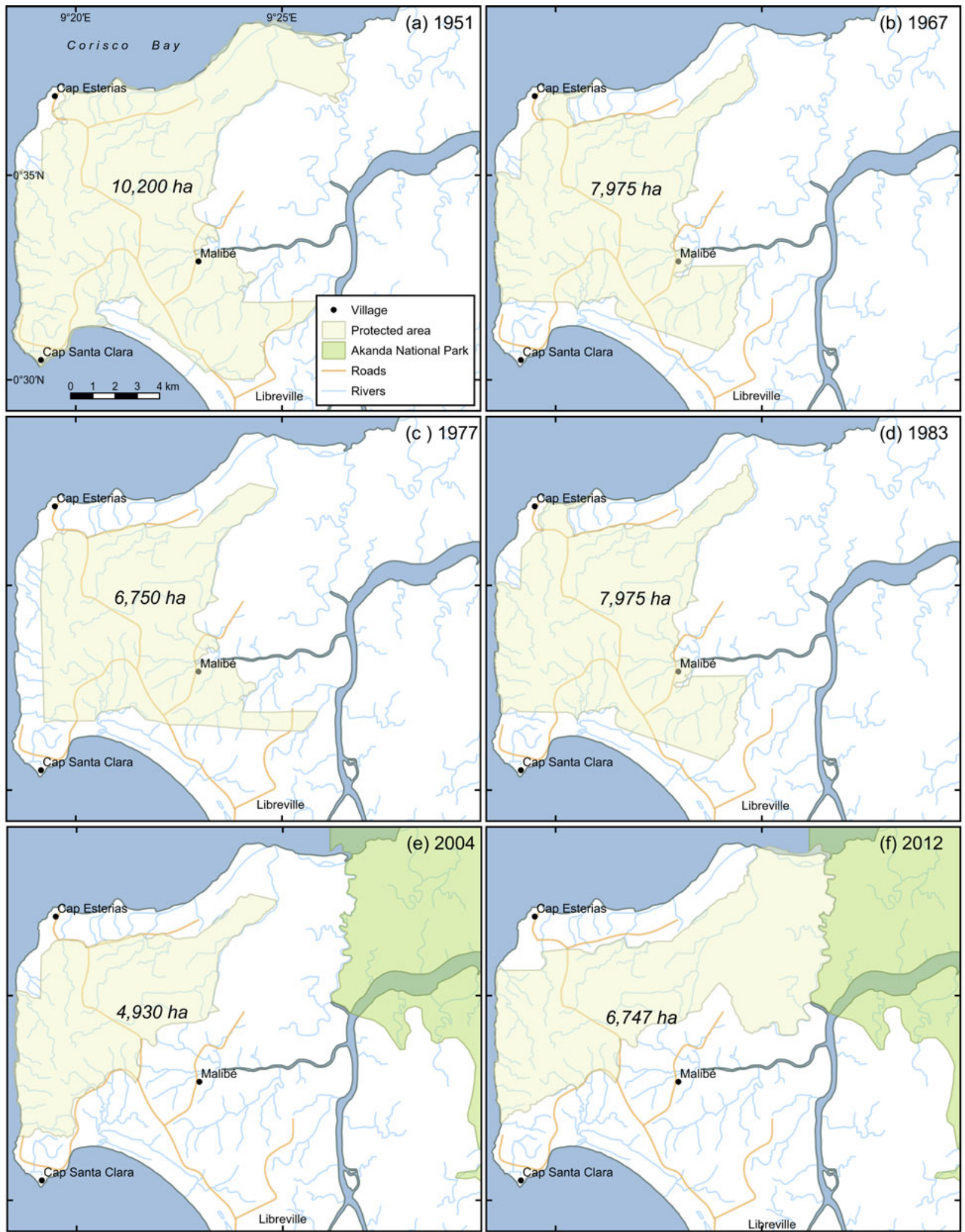

FIG. 2 The boundaries of Forêt Classée de la Mondah in 1951 (a), 1967 (b), 1977 (c), 1983 (d), 2004 (e), and 2012 (f), when the protected area was renamed the Raponda Walker Arboretum. 


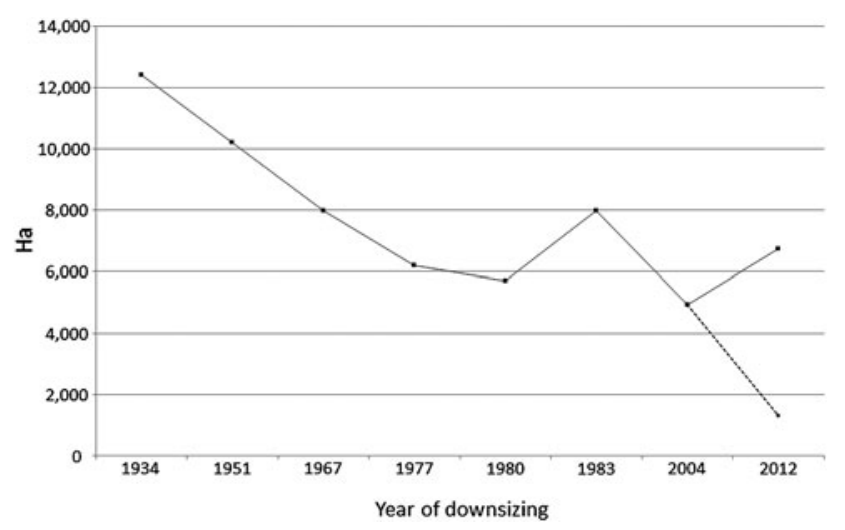

FIG. 3 History of downsizing of Forêt Classée de la Mondah in Gabon (Fig. 1) during 1934-2012. The protected area originally covered 12,400 ha (Ministère des Eaux et Forêt, 1997) but was reduced by successive declassifications in 1951 (Afrique Equatoriale Française, 1951), 1967 (République Gabonaise, 1967), 1977 and 1980 (which were reversed in 1983; République Gabonaise, 1983), 2001 (République Gabonaise, 2001) and 2004 (République Gabonaise, 2004). In 2012 the area was increased to 6,747 ha; the dashed line indicates the proposed reduction to 1,318 ha.

During January-April 2011 fieldwork was conducted at known species localities and in areas or habitats where endemic species were thought to occur. Four of the authors (GW, $\mathrm{OH}, \mathrm{DI}, \mathrm{ENN}$ ) were living on site and worked in the forest daily. Others (OL, TS) specialized in Rubiaceae and Orchidaceae visited the site occasionally, and thus the knowledge of these species and associated success in finding subpopulations was increased. When new subpopulations were discovered, herbarium collections were made and locations were recorded using a global positioning system.

Species threat assessment The study focused on two villages at the southern boundary of the Mondah forest: Santa Clara and Malibé II. These villages are situated between the Mondah forest and Libreville and have been subject to urbanization, migration and development. To understand the threats to habitat and species use, participant observation (residing in the communities) and interviews were conducted in Santa Clara during 2005-2011, with follow-up visits during 20122013. Interviews were conducted in c. 25 randomly chosen households in each village during January-April 2011 to understand the presence and use of both endemic and non-endemic plants in terms of species, category of usage, and utilization of forest space. The questionnaire, which was inspired by other methodologies (e.g. McClatchey et al., 2004), was tested for clarity in a nearby village. After each interview the informant showed the interviewer the plants that had been discussed, and these were collected as herbarium specimens. The specimens were identified, and uses of endemic species were noted. A portable herbarium of the endemic species was presented to informants that were particularly knowledgeable about forest use, to inquire if they knew the species. The results of this ethnobotanical study are reported in detail in Ikabanga (2011).

Assessing the species using IUCN Red List criteria Species were evaluated using the IUCN categories and criteria (IUCN Standards and Petitions Subcommittee, 2013). Maps, produced in ArcView v. 3.1 (ESRI, Redlands, USA), were plotted to calculate the Area of Occurrence and Extent of Occurrence for all endemic plant species in the Mondah forest, and the number of localities was determined. Species were then evaluated, and assessments were submitted to IUCN using the Species Information System tool (IUCN Species Information Service 2.0, 2015).

Ex situ conservation When subpopulations were discovered the area was revisited to procure samples for ex situ conservation trials in Sibang Arboretum and at Jardi-Gab, Libreville. Soil was transported from the sample sites for all trials, and seeds, cuttings and direct transplants were used when possible.

Delimiting the new protected area Species distributions were mapped and threats were categorized based on field observations, interviews and literature. Using the principles of irreplaceability and vulnerability, species conservation priorities were assessed based on the overlap between the proposed protected area and the distributions of the endemic species. Recommendations and data were provided to the National Parks Agency and contributed to the definition of the new boundary of the protected area.

\section{Results}

Endemic species, mapping distributions, and evaluations

Of the 50 species that were hypothesized as endemic to the Libreville peninsula, 24 were verified (Lachenaud et al., 2013b), the others being rejected because records were found outside the study area, or because of revised taxonomy or uncertain identification. Additional subpopulations of nine of these 24 species were identified during fieldwork.

Six sites of conservation importance (e.g. sites containing important subpopulations of endemic species) were found. The majority were located in the Mondah forest but were not restricted to the Centre (Table 2, Fig. 1). The site in the Akanda National Park buffer zone is noteworthy because of the unique presence of Aristogeitonia gabonica. Of the 24 endemic species, seven were not evaluated using the IUCN categories and criteria (undescribed species were not evaluated, as recommended in the Red Listing standards, and the other 
TABLE 1 History of downsizing of the Mondah forest, Gabon (Fig. 3), as reported in government decrees.

\begin{tabular}{|c|c|c|}
\hline Year & Description & Reason for downsizing, as noted in decree \\
\hline 1951 & $\begin{array}{l}\text { Change in status from production forest } \\
\text { to classified forest }\end{array}$ & $\begin{array}{l}\text { Some private inholdings maintained; some concessions given deadlines for ending ac- } \\
\text { tivities; Benga (the main ethnic group at the time) customary usage recognized; exist- } \\
\text { ence of villages \& their cultivation rights recognized; agricultural activities of other } \\
\text { villages ended }\end{array}$ \\
\hline 1967 & Downsizing & Three private properties recognized \\
\hline 1977 & Downsizing & Private properties recognized \\
\hline 1980 & Downsizing & Private properties recognized \\
\hline 1983 & $1977 \& 1980$ decrees cancelled & No reasons given \\
\hline 2001 & Downsizing & Land required for public utilities along road from Libreville to Cap Esterias \\
\hline 2004 & Downsizing & $\begin{array}{l}\text { Two areas removed (for housing construction; authors, pers. obs.); three plots given to } \\
\text { Ministry of Forests }\end{array}$ \\
\hline
\end{tabular}

TABLE 2 Important sites for conservation in and around the Mondah forest, Gabon (Fig. 1), with endemic species present, and habitat type.

\begin{tabular}{|c|c|c|}
\hline Site & Species & Habitat type \\
\hline \multicolumn{3}{|l|}{ Mondah forest } \\
\hline $\begin{array}{l}\text { 1. Parcelle des conservateurs } \\
(0.57506 \mathrm{~N}, 9.33011 \mathrm{E})\end{array}$ & $\begin{array}{l}\text { Gaertnera spicata, Palisota sp. nov. }{ }^{*} \\
\text { Psychotria bracteosa, Psychotria klainei, } \\
\text { Strephonema sp. nov., Uapaca niangadoumae }\end{array}$ & $\begin{array}{l}\text { Hyper-humid forest; humid lowlands; } P \text {. bracteosa } \\
\& \text { U. niangadoumae occurring in wet bottomlands }\end{array}$ \\
\hline $\begin{array}{l}\text { 2. Ferme aux crocodiles } \\
(0.54831 \mathrm{~N}, 9.31033 \mathrm{E})\end{array}$ & $\begin{array}{l}\text { Psychotria wieringae (largest subpopulation), } \\
\text { P. klainei }\end{array}$ & Drier forest \\
\hline $\begin{array}{l}\text { 3. N of Santa Clara } \\
(0.53333 \mathrm{~N}, 9.33333 \mathrm{E})\end{array}$ & Acridocarpus vestitus & Disturbance-loving species, preferring roadsides \\
\hline $\begin{array}{l}\text { 4. Plaine de Combat } 2 \\
(0.58731 \mathrm{~N}, 9.35644 \mathrm{E})\end{array}$ & $\begin{array}{l}\text { Combretum esteriense, Simirestis klaineana, } \\
\text { P. wieringae, U. niangadoumae }\end{array}$ & Drier forest, also in Pongara National Park \\
\hline $\begin{array}{l}\text { 5. Swamp NE of savannah } \\
(0.59133 \mathrm{~N}, 9.36286 \mathrm{E})\end{array}$ & P. bracteosa & $\begin{array}{l}\text { Degraded swamp forest; } P \text {. bracteos } a \text { occurring in a } \\
\text { stream bed }\end{array}$ \\
\hline \multicolumn{3}{|c|}{ Akanda National Park buffer zone } \\
\hline $\begin{array}{l}\text { 6. Oveng }(0.48333 \mathrm{~N} \text {, } \\
\text { 9.51667 E) }\end{array}$ & $\begin{array}{l}\text { Carapa mangarevensis, Aristogeitonia } \\
\text { gabonica* }^{*} \text { Dinklageella villiersi }\end{array}$ & Calcareous outcrops adjacent to mangroves \\
\hline
\end{tabular}

${ }^{*}$ Species occurs uniquely at this site

species were added after the fieldwork concluded, and therefore data were too limited for their assessment), three were categorized as Data Deficient, two as Vulnerable, six as Critically Endangered, and six as Endangered; three of the Critically Endangered species may be extinct (Table 3). Two species that were categorized as Vulnerable in the late 1990s (Dactyladenia laevis and Jollydora pierrei) were again categorized as Vulnerable in the reassessments. Historical information on former distributions was difficult to ascertain because localities recorded for older botanical specimens were imprecise. If historic localities had been more precise, demonstrating the reduction of species distribution over time would have been used as part of the evaluation criteria selected from the IUCN standards.

\section{Ex situ conservation trials}

In the ex situ conservation trials, all attempts to cultivate using seeds and cuttings failed. Only transplants were successful, and these only in the cases of Psychotria bracteosa, Psychotria klainei, Psychotria wieringae, A. gabonica and
Dinklageella villiersii. This is unsurprising because tropical seeds are typically difficult to germinate and often are only viable for a few days (Baskin \& Baskin, 1998). Increased success with cuttings could be possible with the use of a growth hormone.

\section{Threats to habitat and species}

In the 377 herbarium specimens collected for the ethnobotanical study 116 species were identified; none were endemic. No informants, including traditional healers who use the forest flora in their pharmacopeia, were able to indicate additional subpopulations when presented with specimens of endemic plants.

Most habitat uses, such as charcoal production, agriculture, sand production, and traditional medicine, occurred on the forest border and not within the protected area. Most of these activities were using habitat that could have been occupied by endemic species and had previously been part of the protected area. 
TABLE 3 Red List categories of 24 endemic species in the Mondah forest, Gabon (Fig. 1), evaluated using IUCN criteria, with the number of locations where each species has been found, and the species' distribution.

\begin{tabular}{|c|c|c|c|c|}
\hline Species & $\begin{array}{l}\text { Red List } \\
\text { category }\end{array}$ & Red List criteria \& comments & $\begin{array}{l}\text { No. of } \\
\text { locations }\end{array}$ & Distribution $^{2}$ \\
\hline \multicolumn{5}{|l|}{ Apocynaceae } \\
\hline Hunteria hexaloba & $\mathrm{CR}(\mathrm{PE})$ & $\begin{array}{l}\text { Possibly extinct; not collected since } 1902 \\
\text { (Omino, 1996). Not found during searches } \\
\text { of likely localities in the Gabon Estuary in } \\
2007 \text { \& } 2011 \text {. }\end{array}$ & 0 & Libreville peninsula \\
\hline \multicolumn{5}{|l|}{ Celastraceae } \\
\hline S. klaineana & $\mathrm{CR}$ & Blab(i,ii,iii,iv) + 2ab(i,ii,iii,iv); D & $<5$ & Libreville peninsula \\
\hline Salacia villiersii & $\mathrm{DD}$ & & & \\
\hline \multicolumn{5}{|l|}{ Chrysobalanaceae } \\
\hline Dactyladenia laevis & EN & $\mathrm{A} 2 \mathrm{c}$ & $\leq 5$ & Rio Muni \\
\hline \multicolumn{5}{|l|}{ Commelinaceae } \\
\hline Palisota sp. nov. & $\mathrm{NE}$ & & & Mondah forest \\
\hline \multicolumn{5}{|l|}{ Combretaceae } \\
\hline C. esteriense & EN & Blab(i,ii,iii,iv) + 2ab(i,ii,iii,iv); D & & Libreville peninsula \\
\hline Strephonema sp. nov. & $\mathrm{NE}$ & & & Libreville peninsula \\
\hline \multicolumn{5}{|l|}{ Connaraceae } \\
\hline Jollydora pierrei & $\mathrm{VU}$ & D2 & $\leq 5$ & Rio Muni \\
\hline \multicolumn{5}{|l|}{ Convolvulaceae } \\
\hline Calycobolus heineanus & $\mathrm{NE}$ & & & Libreville peninsula \\
\hline \multicolumn{5}{|l|}{ Euphorbiaceae } \\
\hline A. gabonica & $\mathrm{CR}$ & Blab(i,ii,iii,iv) & 1 & Mondah forest \\
\hline U. niangadoumae & $\mathrm{EN}$ & $\mathrm{B} 1 \mathrm{ab}(\mathrm{iii})+2 \mathrm{ab}(\mathrm{iii})$ & $<5$ & Mondah forest \\
\hline \multicolumn{5}{|l|}{ Malpighiaceae } \\
\hline A. vestitus ined. & $\mathrm{NE}$ & & $\leq 5$ & Mondah forest \\
\hline \multicolumn{5}{|l|}{ Melastomataceae } \\
\hline Tristemma vestitum & $\mathrm{NE}$ & & $\begin{array}{l}\text { Unkno- } \\
\text { wn }\end{array}$ & Libreville peninsula \\
\hline \multicolumn{5}{|l|}{ Meliaceae } \\
\hline C. mangarevensis & $\mathrm{NE}$ & & 1 & Mondah forest \\
\hline \multicolumn{5}{|l|}{ Myrsinaceae } \\
\hline Ardisia pierreana & $\mathrm{CR}(\mathrm{PE})$ & $\begin{array}{l}\text { Possibly extinct; not found during searches } \\
\text { of likely localities in } 2007 \text { \& } 2011 \text {. For more } \\
\text { details see Taton (1979). }\end{array}$ & 0 & Libreville peninsula \\
\hline \multicolumn{5}{|c|}{ (2) } \\
\hline Eugenia librevillensis & $\mathrm{DD}$ & & $\begin{array}{l}\text { Unkno- } \\
\text { wn }\end{array}$ & Libreville peninsula \\
\hline \multicolumn{5}{|l|}{ Octoknemaceae } \\
\hline Octoknema klaineana & $\mathrm{DD}$ & & & Libreville peninsula \\
\hline \multicolumn{5}{|l|}{ Orchidaceae } \\
\hline Dinklageella villiersii & $\mathrm{CR}$ & B1a & 1 & Mondah forest \\
\hline \multicolumn{5}{|l|}{ Rubiaceae } \\
\hline G. spicata & EN & $\mathrm{D}$ & 6 & Mondah forest, Rio Muni \\
\hline P. bracteosa & $\mathrm{EN}$ & Blab(i,ii,iii,iv,v) + 2ab(i,ii,iii,iv,v) & 5 & Mondah forest, Rio Muni \\
\hline Psychotria gaboonensis & $\mathrm{CR}(\mathrm{PE})$ & $\begin{array}{l}\text { Possibly extinct; discovered in } 1861 \text { but not } \\
\text { collected since, despite fieldwork. The lo- } \\
\text { cality (Gabon River) is not precise but the } \\
\text { species should be easily recognizable. }\end{array}$ & 0 & Libreville peninsula \\
\hline P. klainei & VU & Blab(i,ii,iii,iv) + 2ab(i,ii,iii,iv) & 6 & Libreville peninsula \\
\hline P. wieringae & $\mathrm{EN}$ & B2ab(ii,iii,iv) & 8 & Mondah forest \\
\hline \multicolumn{5}{|l|}{ Violaceae } \\
\hline Rinorea soyauxii & $\mathrm{NE}$ & & & Libreville peninsula \\
\hline
\end{tabular}

${ }^{1} \mathrm{CR}(\mathrm{PE})$, Critically Endangered (Possibly Extinct); CR, Critically Endangered; DD, Data Deficient; EN, Endangered; NE, Not Evaluated; VU, Vulnerable ${ }^{2}$ Libreville peninsula includes Parc National de Pongara; Mondah forest includes the western buffer zone of Parc National d'Akanda; Rio Muni is in Equatorial Guinea 
The following IUCN threat categories were identified: residential \& commercial development, agriculture \& aquaculture, energy production and mining, and biological resource use. Urbanization was identified as a threat to all the species evaluated, and swidden agriculture, sand exploitation and artisanal logging were identified as threats in $88 \%$ of cases. The main exceptions were the three species (Carapa mangarevensis, D. villiersi, A. gabonica) in the adjacent mangrove habitat characterized by calcareous outcrops, where agriculture, charcoal production and sand exploitation were not evident.

Many informants discussed their use of the forest for ceremonies, and we encountered several ceremonial sites during the study. Some traditional healers regretted the loss of sites as a result of past declassification of the protected area, and noted that the forest was an important cultural resource for them and their clients.

\section{Delimiting the new boundaries}

Species distributions were mapped over the proposed 2010 protected area boundaries. The 24 endemic species assessed were represented in the Mondah forest or in its environs. For 10 strictly endemic species, the global distributions were largely limited to the Mondah forest but not restricted to the Centre. For these species the 2010 proposal would have provided insufficient protection for the majority of their range, and therefore the habitat in the wider Mondah forest was considered to be irreplaceable. All of the species were threatened by urbanization and many were categorized as Endangered or Critically Endangered. As such, these species and their habitats fulfilled both the irreplaceability and vulnerability criteria to be considered a conservation priority (Margules \& Pressey, 2000).

Based on the distribution of the endemic species it was recommended to the National Parks Agency that they maintain the original protected area boundaries rather than the proposed, reduced boundaries, to facilitate conservation of all threatened species. After the mapping of the endemic species was completed we provided data to the National Parks Agency, and assisted in mapping the limits to ensure that the maximum area was protected around endemic subpopulations. The Centre was delimited as the core area, surrounded by a zone where limited development could occur. Additionally, a habitat corridor was created to Akanda National Park. Had the 2010 proposal been accepted the protected area would have been downsized, but instead the area was increased to 6,747 ha. Although the protected area is smaller than the 12,400 ha declared in 1934, the 2012 adjustment succeeded in reversing a trend of continual downsizing.

The declaration was signed into law in October 2012, with the protected area intended to serve the purposes of biodiversity protection, tourism, environmental education, and leisure (République Gabonaise, 2012). The area was renamed the Raponda Walker Arboretum, after the Gabonese ethnobotanist André Raponda Walker, who documented ethnobotany, linguistics and ceremonial rites throughout Gabon (Raponda Walker \& Sillans, 1961, 1962).

\section{Discussion}

Evaluating endemic species in the context of the protected area boundaries facilitated an assessment of irreplaceability. The threat assessment revealed that the plant populations were vulnerable to land conversion, and without this information there would have been little justification to avoid reducing the protected area. Given the uniqueness of the endemic flora of the Libreville peninsula, even when compared to adjacent areas (Dauby et al., 2014), and the current rate of land conversion, without a protected area there would be little chance for the survival of this ecosystem. The transition in management of the area to the National Parks Agency suggests that the area will be managed effectively, including ensuring protection of species. Management plans are under development and include work related to the threatened flora.

Protected area downgrading, downsizing and degazetting is rare in Gabon but it is difficult to avoid completely in urban contexts. Here, the demonstrated presence of endemic species motivated the government to maintain the limits of the protected area, but this is not always the case, even in non-urban situations. In Australia, despite scientific evidence of the presence of endemic species, the government intends to authorize logging in reserves in Victoria (Lindenmayer \& Possingham, 2013). In other cases agribusiness development takes priority, as in the case of the degazettement of forest reserves in Uganda (Mwavu \& Witkowski, 2008) or the proposed degazettement of Gambella National Park in Ethiopia, despite the presence of endemic fauna (Pearce, 2011). In yet other cases, even where endemics are known to occur and are under pressure from urbanization, there are no protected areas, as is the case near Yaoundé, Cameroon (Simo et al., 2009; Lachenaud et al., 2013a); development in and around protected areas along the coast of Cameroon is having a negative impact on the endemic flora (Tchouto et al., 2006).

Many cases of protected area downgrading, downsizing and degazetting are unrecorded (Mascia \& Pailler, 2011), and although urbanization does not appear to be a major threat, recent cases have involved the degradation of forest reserves outside Dar es Salaam as a result of charcoal production (Ahrends et al., 2010) and deforestation in Freetown's peri-urban Western Area Peninsula Forest Reserve (Munro, 2009). Some urban protected areas threatened by development have been saved as a result of activism, such as Nairobi's Uhuru Park (Maathai \& Antinori, 2001). In other 
cases, more land is needed to save endemic species or ecosystems, and agreements with existing landowners are required, as in Capetown (Rebelo et al., 2011).

Many protected area systems were not created originally for biodiversity conservation (Joppa \& Pfaff, 2009) but there is a trend towards systematic conservation planning and cost and management efficiency (Fuller et al., 2010). Analyses of species and habitat protection are now used to set conservation priorities for the creation of protected areas (Callmander et al., 2007; Gereau et al., 2010; Clausnitzer et al., 2012; Holland et al., 2012), using a variety of approaches such as key biodiversity area assessments, and Red List assessment of threatened species (Schatz, 2009) and ecosystems. However, few of the recommendations from these studies seem to be put into practice by state administrations (Brooks et al., 2001). Conservation analyses sometimes reveal that existing protected areas harbour threatened species (e.g. Safi et al., 2013); however, using species distributions to inform the delimitation of new protected area boundaries is rare. There is a significant difference between the processes used in the prescription and application of conservation proposals (Margules \& Pressey, 2000). Here we report on the implementation of one such proposal, which led to the avoidance of downgrading, downsizing and degazetting of a protected area.

Although the reasons for downsizing the protected area in the Mondah forest varied over the years, the downsizing in 2004 was a response to changes in land use. Whereas protected area downgrading, downsizing and degazetting may accelerate deforestation (Forrest et al., 2015), the effects of historical downsizing are less clear. The 2004 downsizing event was a result of urbanization, and the threat of urbanization to all the species assessed shows how downsizing can threaten biodiversity.

The survival of endemic plant species in the Mondah forest despite modern habitat reduction and historical forest use is striking. Gaertnera spicata was first collected in the 1800 in present-day Sibang Arboretum, $8 \mathrm{~km}$ east of Libreville and now part of the city; today, the species remains only in the Centre, in a rare micro-habitat. Although none of the endemic species were used directly by people, all were threatened indirectly by habitat conversion. In areas where habitat diversity is high, it appears threatened species may persist in microhabitats under conditions of rapid land conversion. After more than a century of botanical research new species continue to be found in the Mondah forest. In addition to the three species for which descriptions were published recently (Kenfack, 2011; Breteler, 2012; Lachenaud et al., 2013b), others remain undescribed, a phenomenon typical of countries with limited botanical inventories (Campbell \& Hammond, 1989).

Despite the existing herbarium specimen information, which can indicate a species' distribution, there is a lack of confirmation of the specific location of many subpopulations, particularly for species categorized as Data Deficient or for those that were Not Evaluated. More work is needed to expand ex situ conservation, such as disseminating propagules of these rare species in public gardens as part of an environmental education programme, contributing to efforts underway in the Raponda Walker Arboretum. Two species in particular (A. vestitus and G. spicata) have high ornamental value.

Protected areas, particularly in urban areas, supply a range of human needs. The Raponda Walker Arboretum is simultaneously a critical habitat for endemic species and a religious-cultural space, the Mondah being one of the closest forests to Libreville and one of the most accessible. The creation of the Arboretum is an exemplary step in protecting irreplaceable habitats of rare species while providing forest for cultural activities, environmental education, and leisure.

\section{Acknowledgements}

We thank John Mitchell and the Beneficia Foundation for believing in this project. This project supported two MSc theses at the Université des Sciences et Techniques de Masuku. All researchers were hosted by IPHAMETRA (the Institute of Pharmacopeia and of Traditional Medicine). Administrative assistance was provided by the Wildlife Conservation Society-Gabon. Research permission was obtained from the Centre National de la Recherché Scientifique et Technique, École Nationale des Eaux et Forêts and the Gabon National Parks Agency. Field assistance was provided by E. Augowet Bonguno, S. Dessein, P. Christy, J-N. Boussiengui, L. Moungoudy, P. Koumba Ipandi, J.R. Ondzaghe and B. Bouligui. P. Christy found the decrees for the declassification. The residents of Santa Clara and Malibé II welcomed us warmly and granted access. The following herbaria gave us access to their collections: LBV, BR, BRLU and WAG. OL was a research fellow of the Fonds National de la Recherche Scientifique. This paper benefited from comments by N. Burgess, S. Regnaut, R. Gereau, M. Lee and an anonymous reviewer. We are grateful to Martin Fisher for his work in finalizing the maps for Figure 3.

\section{References}

Afrique Equatoriale Française (1951) Arreté no. 348/SF, 16 février 1951 portant classement de la réserve forestière de la Mondah. Journal Officiel de l'Afrique Equatoriale Française, 6, 452-453.

Ahrends, A., Burgess, N., Milledge, S.A.H., Bulling, M.T., Fisher, B., SMArt, J.C.R. et al. (2010) Predictable waves of sequential forest degradation and biodiversity loss spreading from an African city. Proceedings of the National Academy of Sciences of the United States of America, 107, 14556-14561.

Aronson, M.F.J., La Sorte, F.A., Nilon, C.H., Katti, M., Goddard, M.A., LEPCZYK, C.A. et al. (2014) A global analysis of the impacts of 
urbanization on bird and plant diversity reveals key anthropogenic drivers. Proceedings of the Royal Society B, 281, 20133330.

BASKIn, C.C. \& BASKIN, J.M. (1998) Seeds: Ecology, Biogeography, and Evolution of Dormancy and Germination. Academic Press, San Diego, USA.

Breteler, F. (2012) Novitates Gabonenses 71. A new species of Uapaca (Phyllanthaceae, formerly Euphorbiaceae) from Gabon. Plant Ecology and Evolution, 145, 129-131.

Brooks, T., Balmford, A., Burgess, N., Fjelds ̊̊, J., Hansen, L.A., Moore, J. et al. (2001) Toward a blueprint for conservation in Africa. BioScience, 51, 613-624.

Callmander, M.W., Schatz, G.E., Lowry, P.P., Laivao, M.O., Raharimampionona, J., Andriambololonera, S. et al. (2007) Identification of priority areas for plant conservation in Madagascar using Red List criteria: rare and threatened Pandanaceae indicate sites in need of protection. Oryx, 41, 168-176.

Campbell, D.G. \& Hammond, H.D. (1989) Floristic Inventory of Tropical Countries: The Status of Plant Systematics, Collections, and Vegetation, Plus Recommendations for the Future. New York Botanical Garden, New York, USA.

Chape, S., Spalding, M. \& Jenkins, M. (eds) (2008) The World's Protected Areas: Status, Values and Prospects in the 21st Century. University of California Press, Berkeley, USA.

Clausnitzer, V., Dijkstra, K.-D.B., Koch, R., Boudot, J.-P., Darwall, W.R.T., Kipping, J. et al. (2012) Focus on African freshwaters: hotspots of dragonfly diversity and conservation concern. Frontiers in Ecology and the Environment, 10, 129-134.

Clist, B. (2005) Des premiers villages aux premiers européens autour de l'estuaire du Gabon: quatre millénaires d'interactions entre l'homme et son milieu. $\mathrm{PhD}$ thesis. Université Libre de Bruxelles, Brussels, Belgium.

COmifaC (Commision des Forêts d'Afrique Centrale) (2010) Les forêts du Bassin du Congo: Etat des Forêts 2010. COMIFAC, Yaoundé, Cameroon.

Dauby, G., Hardy, O.J., Leal, M., Breteler, F. \& Stévart, T. (2014) Drivers of tree diversity in tropical rain forests: new insights from a comparison between littoral and hilly landscapes of Central Africa. Journal of Biogeography, 41, 574-586.

Dauby, G., Leal, M. \& Stévart, T. (2008) Vascular plant checklist of the coastal National Park of Pongara, Gabon. Systematics and Geography of Plants, 78, 155-216.

DeFries, R.S., Rudel, T., Uriarte, M. \& Hansen, M. (2010) Deforestation driven by urban population growth and agricultural trade in the twenty-first century. Nature Geoscience, 3, 178-181.

Delnotal, T. (2009) Exploitation durable des plantes médicinales dans la forêt de la Mondah-Gabon; inventaire et perspectives. MSc thesis. Université Paul Sabatier-Toulouse III, Toulouse, France.

Deschamps, H. (1962) Traditions orales et archives au Gabon. Berger-Levrault, Paris, France.

Doumenge, C., Ndinga, A., Nembot, T.F., Tchanou, Z., Ondo, V. M., Nze, N.O. et al. (2003) Conservation de la biodiversité en Afrique centrale atlantique II. Identification d'un réseau de sites critiques. Bois et Forêts des Tropiques, 276, 43-58.

East, T., Kümpel, N.F., Milner-Gulland, E.J. \& Rowcliffe, J.M. (2005) Determinants of urban bushmeat consumption in Rio Muni, Equatorial Guinea. Biological Conservation, 126, 206-215.

Elmovist, T., Fragkias, M., Goodness, J., Güneralp, B., Marcotullio, P.J., McDonald, R.I. et al. (2013) Urbanization, Biodiversity and Ecosystem Services: Challenges and Opportunities: A Global Assessment. Springer, Dordrecht, Netherlands.

Forrest, J.L., Mascia, M.B., Pailler, S., Zuraidah Abidin, S., Araujo, M.D., Krithivasan, R. \& Riveros, J.-C. (2015) Tropical deforestation and carbon emissions from protected area downgrading, downsizing, and degazettement (PADDD). Conservation Letters, 8, 153-161.

Fuller, R.A., McDonald-Madden, E., Wilson, K.A., Carwardine, J., Grantham, H.S., Watson, J.E.M. et al. (2010) Replacing underperforming protected areas achieves better conservation outcomes. Nature, 466, 365-367.

Gereau, R., Luke, W.R.Q., Kindeketa, W., Bodine, S. \& Schatz, G. (2010) Plant conservation assessments in East Africa: procedures and first results. In Systematics and Conservation of African Plants (eds X. van der Burgt \& L.J.G. van der Maesen), pp. 471-475. Royal Botanic Gardens, Kew, UK.

Gordon, I.J., Acevedo-Whitehouse, K., Altwegg, R., Garner, T.W.J., Gompper, M.E., Katzner, T.E. et al. (2012) What the 'food security' agenda means for animal conservation in terrestrial ecosystems. Animal Conservation, 15, 115-116.

Hansen, M.C., Potapov, P.V., Moore, R., Hancher, M., Turubanova, S.A., Tyukavina, A. et al. (2013) High-resolution global maps of 21st-century forest cover change. Science, 342, $850-853$.

Harris, D.J., Armstrong, K.E., Walters, G.M, Wilks, C., Mouandza Mbembo, J.-C., Niangadouma, R. et al. (2012) Phytogeographical analysis and checklist of the vascular plants of Loango National Park, Gabon. Plant Ecology and Evolution, 145, 242-257.

Holland, R.A., Darwall, W.R.T. \& Smith, K.G. (2012) Conservation priorities for freshwater biodiversity: the Key Biodiversity Area approach refined and tested for continental Africa. Biological Conservation, 148, 167-179.

IкаваNGA, D.U. (2011) Utilisation de l'espace forêt et ses espèces végétales par deux communautés sud de la Forêt Classée de la Mondah, Gabon. MSc thesis. Université des Sciences et Techniques de Masuku, Franceville, Gabon.

IUCN Species Information Service 2.0 (2015) Https://sis.iucnsis. org/apps/org.iucn.sis.server/SIS/index.html [accessed 7 April 2015].

iUCN Standards and Petitions Subcommittee (2013) Guidelines for Using the IUCN Red List Categories and Criteria, Version 10. IUCN, Gland, Switzerland.

Joppa, L.N. \& PFAFF, A. (2009) High and far: biases in the location of protected areas. PLoS ONE, 4(12), e8273.

Keith, D.A., Rodríguez, J.P., Rodríguez-Clark, K.M., Nicholson, E., Aapala, K., Alonso, A. et al. (2013) Scientific foundations for an IUCN Red List of ecosystems. PLoS ONE, 8(5), e62111.

KenfaCK, D. (2011) Resurrection in Carapa (Meliaceae): a reassessment of morphological variation and species boundaries using multivariate methods in a phylogenetic context. Botanical Journal of the Linnean Society, 165, 186-221.

Koumba-Madingou, N.-O. (2009) Contribution à l'étude de quelques plantes utiles en médicine traditionnelle dans le traitement des maladies cardiovasculaire (hypertension-artérielle) au Gabon. $\mathrm{PhD}$ thesis. Ecole Doctorale Régionale du RA-Biotech, Université d'Ouagadougou, Ouagadougou, Burkina Faso.

Lachenaud, O. (2009) La flore des plantes vasculaires de la République du Congo: nouvelles données. Systematics and Geography of Plants, 79, 199-214.

Lachenaud, O., Droissart, V., Dessein, S., Stévart, T., Simo, M., Lemaire, B. et al. (2013a) New records for the flora of Cameroon, including a new species of Psychotria (Rubiaceae) and range extensions for some rare species. Plant Ecology and Evolution, 146, 121-133.

Lachenaud, O., Stévart, T., Ikabanga, D.U., Ndjabounda, E.C. N. \& Walters, G. (2013b) Les forêts littorales de la région de Libreville (Gabon) et leur importance pour la conservation: 
description d'un nouveau Psychotria (Rubiaceae) endémique. Plant Ecology and Evolution, 146, 68-74.

Lindenmayer, D.B. \& Possingham, H.P. (2013) No excuse for habitat destruction. Science, 340, 680 .

MaAthai, W. \& Antinori, S. (2001) The good, the bad, and the ugly. The Ecologist, 31, 24.

Magle, S.B., Hunt, V.M., Vernon, M. \& Crooks, K.R. (2012) Urban wildlife research: past, present, and future. Biological Conservation, 155, 23-32.

Margules, C.R. \& Pressey, R.L. (2000) Systematic conservation planning. Nature, 405, 243-253.

Mascia, M.B. \& Pailler, S. (2011) Protected area downgrading, downsizing, and degazettement (PADDD) and its conservation implications. Conservation Letters, 4, 9-2O.

Mascia, M.B., Pailler, S., Krithivasan, R., Roshchanka, V., Burns, D., Mlotha, M.J. et al. (2014) Protected area downgrading, downsizing, and degazettement (PADDD) in Africa, Asia, and Latin America and the Caribbean, 1900-2010. Biological Conservation, $169,355-361$.

McClatchey, W.C., Thaman, R. \& Juvik, S. (2004) Ethnobiodiversity surveys of human/ecosystem relationships. In Biodiversity Assessment of Tropical Island Ecosystems (eds D. Mueller-Dombois, K.W. Bridges \& C.C. Daehler), pp. 157-194. Bishop Museum Press, Honolulu, USA.

McDonald, R.I., Kareiva, P. \& Forman, R.T.T. (2008) The implications of current and future urbanization for global protected areas and biodiversity conservation. Biological Conservation, 141, $1695-1703$.

Meye, F. (1969) Les Coupeurs de Bois. African Arts, 2, 57-59.

Ministère des Eaux et Forêts (1997) Plan d'aménagement forestier 1997-2006 (Forêt Classée de la Mondah). GTZ Projet de Réhabilitation de l'Ecole Nationale des Eaux et Forêts, Libreville, Gabon.

Múller, H. \& Eriksson, O. (2013) A pragmatic and utilitarian view of species translocation as a tool in conservation biology. Biodiversity and Conservation, 22, 1837-1841.

Munro, P.G. (2009) Deforestation: constructing problems and solutions on Sierra Leone's Freetown Peninsula. Journal of Political Ecology, 16, 104-122.

Mwavu, E.N. \& Witkowski, E.T.F. (2008) Land-use and cover changes (1988-2002) around Budongo Forest Reserve, NW Uganda: implications for forest and woodland sustainability. Land Degradation \& Development, 19, 606-622.

Nziengui, M., Nana, A., Oslisly, R., Tchindjan, M., Mapaga, D., Ropivia, M.L. et al. (2008) Suivi par télédétection de la dynamique des milieux savanicoles et forestiers gabonais. Exemples de la forêt classée de la Mondah et du parc national de la Lopé. PhotoInterprétation, 44, 14-23.

Омаломво, J. (2005) Kisangani: a city at its lowest ebb. In Urban Africa: Changing Contours of Survival in the City (eds A. Simone \& A. Abouhani), pp. 96-119. Zed Books, London, UK.

OMino, E.A. (1996) A contribution to the leaf anatomy and taxonomy of Apocynaceae in Africa. Wageningen Agricultural University Papers, 96-1.

OnAnA, J.M. (2010) Endémisme floristique du Cameroun: inventaire systématique et conservation de la biodiversité. In Systématiques et Conservation des Plantes Africaines (eds X. van der Burgt \& L.J. G. van der Maesen), pp. 509-521. Royal Botanic Gardens, Kew, UK.

Patterson, K.D. (1975) The Northern Gabon Coast to 1875. Clarendon Press, Oxford, UK.

Pearce, F. (2011) Agribusiness boom threatens key African wildlife migration. Yale Environment 36o. Http://e36o.yale.edu/feature/ agribusiness_boom_threatens_key_african_wildlife_migration/ 2377/ [accessed 3 March 2015].
Quilliard, M.C. (1920) Les Exploitations Forestières du Gabon. In Congrès d'Agriculture Coloniale 21-25 Mai 1918. Compte Rendu des Travaux.Tome IV Agriculture Indigène Elevage, Hygiène, Forêt, Pêcheries, pp. 642-667.

Raponda Walker, A. \& Sillans, R. (1961) Les Plantes Utiles $d u$ Gabon. Le Chevalier, Paris, France.

Raponda Walker, A. \& Sillans, R. (1962) Rites et croyances des peuples $d u$ Gabon. Présence Africaine, Paris, France.

Rebelo, A.G., Holmes, P.M., Dorse, C. \& Wood, J. (2011) Impacts of urbanization in a biodiversity hotspot: conservation challenges in Metropolitan Cape Town. South African Journal of Botany, 77, 20-35.

République Gabonaise (1967) Arrêté no.1297/SF, 24 octobre 1967 déclassement trois parcelles de forêt de la forêt classée de la Mondah.

République Gabonaise (1983) Décretn no.1403/PR/MEFCR, 17 octobre 1983 annulant les arrêtés nº56/PR/MEFCR-ENEF du 4 Août 1977 et n ${ }^{\circ} 692 / \mathrm{PR} / \mathrm{MEF}-\mathrm{ENEF}$ du 24 mars 1980, portant déclassement de trois parcelles de Ia forêt classée de la Mondah.

République Gabonaise (2001) Décret no.719/PR/MECV du 3 juillet 2001 portant déclaration d'utilité publique de I'occupation de zones bordant la route départementale du Cap-Estérias.

République Gabonaise (2004) Décret no.34/PR/MEFEPEPN du 22 janvier 2004 portant déclassement de deux parcelles à l'intéieur de la forêt classée de la Mondah.

République Gabonaise (2007) Loi no. 003/2007 du 27 aout 2007 relative aux Parcs Nationaux. Journal Officiel de la République Gabonaise, 10.

République Gabonaise (2012) Decret no.046o/PR/MEF portant classement de l'Arboretum Raponda-Walker.

Safi, K., Armour-Marshall, K., Baillie, J.E.M. \& IsaAC, N.J.B. (2013) Global patterns of evolutionary distinct and globally endangered amphibians and mammals. PLOS ONE, 8(5), e63582.

SCHatz, G.E. (2009) Plants on the IUCN Red List: setting priorities to inform conservation. Trends in Plant Science, 14, 638-642.

Simo, M., Droissart, V., Sonké, B. \& Stévart, T. (2009) The orchid flora of the Mbam Minkom Hills (Yaoundé, Cameroon). Belgian Journal of Botany, 142, 111-123.

Smith, P., Gregory, P.J., van Vuuren, D., Obersteiner, M., Havlik, P., Rounsevell, M. et al. (2010) Competition for land. Philosphical Transactions of the Royal Society of London, B, 365, 2941-2957.

SocPA, A. (2010) New kinds of land conflict in urban Cameroon: the case of the 'landless' indigenous peoples in Yaoundé. Africa, 8o, 553-572.

Sosef, M.S.M., Wieringa, J.J., Jongkind, C.C.H., Achoundong, G., Issembe, Y.A., Bedigian, D. et al. (2006) Check-list des plantes vasculaires du Gabon. Scripta Botanica Belgica, 35.

TAton, A. (1979) Contribution à l'étude du genre Ardisia Sw. (Myrsinaceae) en Afrique tropicale. Bulletin du Jardin Botanique National de Belgique, 49, 81-120.

Tchouto, M.G.P., Yemefack, M., De Boer, W.F., de Wilde, J.J.F.E., van der Maesen, L.J.G. \& Cleef, A.M. (2006) Biodiversity hotspots and conservation priorities in the Campo-Ma'an rain forests, Cameroon. Biodiversity and Conservation, 15, 1219-1252.

Theobald, D.M., Hobbs, N.T., Bearly, T., Zack, J.A., Shenk, T. \& Riebsame, W.E. (2000) Incorporating biological information in local land-use decision making: designing a system for conservation planning. Landscape Ecology, 15, 35-45.

Trefon, T. (2003) Libreville's evolving forest dependencies. In Culture, Ecology, and Politics in Gabon's Rainforests (eds M.C. Reed \& J.F. Barnes), pp. 37-62. Edwin Mellon Press, Lewiston, USA.

United Nations (2014) World Urbanization Prospects: The 2014 Revision, Highlights (ST/ESA/SER.A/352). United Nations Department of Economic and Social Affairs, Population Division, New York, USA. 
VAnde Weghe, J.P. (2005) Les parcs nationaux du Gabon. Akanda et Pongara: plages et mangroves. Wildlife Conservation Society, Libreville, Gabon.

White, F. (1983) The Vegetation of Africa: A Descriptive Memoir to Accompany the UNESCO/AETFAT/UNSO Vegetation Map of Africa. UNESCO, Paris, France.

WiLKs, C. (1990) La conservation des écosystemes forestiers du Gabon. IUCN, Gland, Switzerland.

\section{Biographical sketches}

Gretchen Walters works in Central Africa on plant diversity, fire management, and human dimensions of conservation. EDDY NGAGNIA works on floristics. DAVY IKABANGA researches the genetics of tropical trees. JEAN-Phillipe Biteau focuses on cultivating native species from Gabon. Olivier Hymas works on the human dimension of conservation in light of environmental history. L.J.T. White directs Gabon's National Parks and focuses on biodiversity conservation. AnNE-MARIE NDONG OBIANG is the Conservator of the Raponda Walker Arboretum. PARFAit NDONG ONDO is the National Parks Agency's geographical information system specialist. KATHRYN JEFFERY works on primates, fire and management and is the Scientific Advisor to the National Parks Agency. Olivier Lachenaud studies plant diversity in the tropics, focusing on the Rubiaceae. TAR IQ S TÉVART studies plant diversity and conservation in Africa, focusing on orchids. 